\title{
THE ANNALS
}

$\triangle N D$

\section{MAGAZINE OF NATURAL HISTORY. \\ [NINTH SERIES.]}

No. 51. MARCH 1922.

XXV.-The African Species of Ebæus, Er., with an Account of their accessory o-characters [Coleoptera]. By G. C. Champion, F.Z.S.

The present paper, in continuation of the one on Hedybius and its allies published in the last volume of this Magazine (pp. 449-494), is based upon a study of the African Ebci belonging to the Cape Town and Durban Museums and the British Museum in London. With two exceptions, they are all from South or East Africa, and about half of them are treated as new, the remainder having been described by Boheman, J. Thomson, Abeille de Perrin, Gorham, and Pic, and placed by them under various generic names *.

\section{Eвеus.}

Ebaus, Erichson, Entomographien, p. 113 (1840) [type E. pedicularius, Schrank].

Urodactylus, J. Thomson, Archives Ent. ii. p. 80 (1858) [type U. bicaudatus, Thoms.].

Attalus, Er., subgen. Mixis, Abeille de Perrin, Rev. d'Ent. ix. p. 51 (1890); Ann. Soc. Ent. Fr. 1890, p. 407 (1891) [type Ebreus hystrix, Ab.].

* The East African forms, one of which is referred to Ebceus, named by Pic in 1919, " pour prendre date," are not recognisable from the brief diagnoses given. Anthocomus coriaceus, Gorh. (1905), is a Dasytid. Ann. \& Mag. N. Hist. Ser. 9. Vol. ix. 
Ebaomorphus, Pic, L'Echange, xx. p. 28 (1904) [nec Attalus, subgen. Ebcimorphus, Abeille de Perrin, Ann. Soc. Ent. Fr. 1890, p. 578 (1891)] [type E. ramicornis, Pic].

The Ethiopian insects here referred to Ebcus differ from their northern allies in the armature or shape of the apices of the elytra in the $\delta$; the appendages when fully developed ( $E$. bicaudatus) are not like those of the type of the genus (E. pedicularius, Schrank), and when absent (E. inermipennis, Pic, \&c.) are replaced by a tumid, smooth, or hollow space. In Ebaus, s. str., ơ, there are two appendages-a small inner one and a large subtriangular, earshaped, or oblong, apical or outer one, the latter retractile and partially closing the terminal cavity. This structure is not to be found in the southern forms, nevertheless the name Urodactylus, J. Thoms. (= Mixis, Ab.), caunot be retained for them. Abeille de Perrin attached too much importance to the surface-vestiture-wholly fine and sericeous in Ebceus, and with intermixed longer hairs or erect setæ in Mixis, a character that cannot be regarded as of generic value. The flabellate or pectinate antennæ in the $\delta$ (E. ramicornis, Boh., apricus, Gorh., \&c.) is an unimportant secondary sexual character occurring also in Malachius and Hapalochrus. Ebaus therefore, in the wide sense, is separable from Attalus, which has similar anterior tarsi in $\delta^{*}$, by the appendiculate or peculiarly-formed apices of the elytra in this sex, the head wanting the frontal excavation so conspicuous in the males of Hebybius, \&c. The simple tarsal structure of Anthocomus distinguishes that genus from Attalus and Ebceus.

\section{of $\sigma^{*}$.}

1 (14). Antennæ serrate or subserrate, the joints obconic in No. 19.

2 (7). Prothorax narrowly margined; elytra with fine sericeous pubescence, opaque or subopaque, the apices excavate and also lamellate or dentate; anterior tarsal joint 2 nigro-pectinate at tip. [ЕвжUs, Er.]

3 (6). Elytra metallic.

4 (5). Legs, head, prothorax, scutellum, \&c., testa-

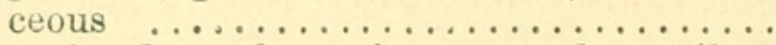

5 (4). Legs, head, prothorax in part, and scutellum metallic ................... Species 2 .

* $q$ o only known of Nos. 14, 23-30, 33: these species are not included in the Table. 
6 (3). Elytra maculate, at least at tip, not metallic ;

legs infuscate, except in No. 6 .........

7 (2). Prothorax more broadly margined; elytra

Species 3-6. usually with longer bristly or erect hairs intermixed, maculate.

8 (11). Elytral apices transversely excavate and each with a long, curved or angulate appendage arising from the suture. [URODACTYLUS, J. Thoms. = Mixis, Ab.]

9 (10). Anterior tarsal joint 2 elongated, nigropectinate at apex and along outer edge; posterior tibiæ simply curved ..........

10 (9). Anterior tarsal joint 2 nigro-pectinate at apex only; posterior tibiæ bisinuate in No. 10, dilated near base in No. $11 \ldots .$.

11 (8). Elytral apices transversely depressed or excavate, and also lamellate, tumid, or subdentate.

12 (13). Anterior tarsal joint 2 elongated, nigropectinate at apex and along outer edge; intermediate tibiæ tumid near base and strongly sinuate in No. $19 \ldots \ldots \ldots \ldots$. . .

13 (12). Anterior tarsal joint 2 nigro-pectinate at apex only; intermediate tibiæ sinuate in No. 21.

14 (1). Antennæ sharply dentate, pectinate, or flabellate; elytral apices more or less excavate, and also tumid, lamellate, or dentate, simply smoother and obliquely truncate in No. 36; elytra with longer hairs intermixed. [NEPACHys, G. Thoms.; EвдомоRphus, Pic, nec Ab.]

15 (16). Elytra metallic (except at tip in No. 32), opaque or shining; antennæ dentate and posterior tibiæ bisinuate in No. 31, the antennæ pectinate in No. 32 ; anterior tarsal joint 2 nigro-pectinate at apex ....

16 (15). Elytra (except in No. 34, var.) maculate; anterior tarsal joint 2 nigro-pectinate at tip and along outer edge $\ldots \ldots \ldots \ldots \ldots$ Species $34-36$.

\section{Ebaus conigerus, sp. n.}

$\delta$. Moderately elongate, convex, widened posteriorly, the elytra opaque, the rest of the surface shining, very finely sericeo-pubescent; rufo-testaceous, the antennal joints 7-11 in great part, and the eyes, black, the elytra purplishviolaceous, blue at the base; the head and prothorax almost smooth, the elytra alutaceous, excessively minutely punctate. Head longitudinally bi-impressed in front; antennæ long, rather stout, serrate. Prothorax convex, transverse, rounded at the sides, strongly, obliquely narrowed posteriorly, very narrowly margined. Elytra moderately 
long, rounded at the sides posteriorly ; sinuate-truncate and deeply, abruptly, transversely excavate at the apex, the excavation limited externally by a long, stout, inferiorlyhollowed, conical prominence, the sutural angle also raised and angulate. Posterior tibiæ curved. Anterior tarsal joint 2 projecting over the base of 3 , black at the tip.

Length $3 \mathrm{~mm}$.

Hab. Rhodesia, Salisbury (Dr. Marshall: x. 1899).

One specimen. A rufo-testaceous insect, with opaque, purplish-violaceous elytra, the latter strongly bidentate at the apex in $\delta$, the five outer joints of the antennæ partly or wholly black. E. (Mixis) rufithorax, Pic, on, has a similar, but shorter, conical tubercle at the outer apical angle of the elytra. The outer tubercle in $E$. conigerus is hook-like when viewed in profile.

\section{Ebaus nairobianus, sp. $\mathrm{n}$.}

§. Elongate, widened posteriorly, very finely pubescent, the head and prothorax very shining, the elytra (except at the base) opaque; obscure metallic green, the sides of the prothorax broadly, and the abdomen (the black tip excepted), rufo-testaceous, the antennal joints $1-4$ (except 1 above), and the anterior tarsi at the base, testaceous, the rest of the antennæ black. Head barely as wide as the prothorax, almost smooth, bi-impressed in front; antennæ long, serrate. Prothorax transverse, convex, almost smooth, rounded at the sides, narrowed posteriorly. Elytra incompletely covering the abdomen, very finely shagreened and with an indication of two faint raised lines on the disc; constricted and sinuato-truncate at the apex, deeply, transversely excavate before the tip, the excavation polished within and bordered on each side behind by a rather broad, tumid, projecting lamella. Anterior tarsal joint 2 extending over the base of 3 .

Length $3 \frac{1}{2} \mathrm{~mm}$.

Hab. E. Africa, Ngong Forest, Nairobi (A. F. J. Gedye: 18. x. 1920).

One $\delta$, presented to the British Museum. More elongate and larger than the S. African E. ramicornis, Boh., the elytra wholly metallic, the abdomen red, except at the tip, the antennæ simply serrate in $\delta$. 


\section{Ebreus rubricatus, sp. n.}

$\delta$. Elongate, widened posteriorly, the elytra opaque, the rest of the surface somewhat shining, finely sericeo-pubescent; black, the antennal joints 1-5 (except 1 above) and 11 in part, the sides of the prothorax broadly, and the elytra (a common oblong spot on the suture before the tip excepted) testaceous; extremely finely, closely punctate. Head, antennæ, thorax, and elytra as in E. martini and dunbrodensis, Pic; elytra transversely excavate before the tip, the apical margin tumid and subangulate externally, and with a narrow, rather long, blunt process arising from each sutural angle; anterior tarsal joint 2 extending over 3 above.

Length $3 \mathrm{~mm}$.

Hab. E. Africa, Port Natal [Durban] (ex coll. Fry).

One male. This is one of four closely-related S. African insects, separable, inter $s e$, apart from colour-differences, by the shape of the apices of the elytra in $\delta$. The structure of the anterior tarsi in this sex excludes them from Anthocomus.

\section{Ebaus martini.}

Anthocomus martini and var. natalensis, Pic, L'Echange, xx. p. 27 (o ㅇ) (1904) ${ }^{1}$.

๙. Antennæ long, rather stout, subserrate; elytra obliquely sinuato-excavate and bilamellate at the tip, the lamellæ truncate and feebly emarginate, the upper one placed above the cavity externally and the other at the sutural angle; anterior tarsal joint 2 prolonged over the base of 3 above, black at the tip.

. Antennæ shorter; elytra with the apical margin simply tumid.

Hab. S. Africa, Natal ${ }^{1}$ (type of Pic), Malvern (Mus. Durban: $\delta$ o ).

A variable insect; the elytra usually with an ante-median fascia and a common apical spot on the suture before the apex testaceous, sometimes bluish-black (the testaceous apex excepted) in $\delta$, the fascia in this case being indicated by greyish pubescence. The upper surface is opaque and finely sericeo-pubescent. According to Pic, the first joint ( $=$ second) of the anterior tarsi is prolonged in $\delta$. An imperfect specimen of the same sex from Zululand (Mus. Cape Tuwn) may also belong here. 


\section{Ebaus dunbrodensis.}

Anthocomus martini, var. dunbrodensis, Pic, L'Echange, xxvii. p. 156 $(1911)^{1}$.

o. Elytra obliquely sinuato-excavate at the apex, and with a transverse, laterally-angulate lamella within the apical margin externally, the sutural angles obliquely truncate; the other characters as in E. martini, Pic.

Hab. S. Arrica, Dunbrody ${ }^{1}$ (Mus. Cape Town: ơ $q$ ), Grahamstown (ex coll. Fry: $q$ ).

One $\delta$ and three $q q$ seen. Separable from $E$. martini by the uni-lamellate apices of the elytra in the $\delta$; the markings of the latter are also different, there being no trace of a common subapical testaceous spot in the present insect. The development of the black portion of the prothorax is variable in both of them.

\section{Ebæus sericatus, sp. n.}

q. Moderately elongate, convex, widened posteriorly, opaque, very finely sericeo-pubescent; black, the basal six or seven antennal joints, the prothorax (a triangular or oblong patch on the anterior part of the disc excepted), the legs (the femora in part excepted), and the abdomen in part, testaceous or rufo-testaceous; the elytra flavous, each with a large triangular patch at the base and a rounded or subangular space towards the apex (these markings connected along the middle of the disc in one of the Beira specimens) bluish-black; the head and prothorax almost smooth, the elytra alutaceous, excessively minutely punctate. Head narrower than the prothorax; antennæ rather stout, short, serrate. Prothorax transverse, convex, rounded at the sides, very narrowly margined. Elytra simply rounded at the apex. Posterior tibix curved.

o. Anterior tarsal joint 2 raised above the base of 3 ; elytra with the apical margin tumid and lamellato-truncate, angularly projecting externally, the tumid space not preceded by a deep sinnous groove as in E. dunbrodensis; pygidium testaceous.

Var. o. The elytral markings black and connected down the middle of the disc, the head and prothorax wholly rufo-testaceous.

Length $2 \frac{1}{10}-2 \frac{9}{10} \mathrm{~mm}$.

Hab. S. Africa, Salisbury, Rhodesia [type], Beira [var.] (Dr. Marshall: ix. 1900, x. 1908). 
Two $\delta \delta$ and one $q$ of the Rhodesian form, two $q q$ from Beira. Exactly like $E$. dunbrodensis, Pic, but with the apices of the elytra differently shaped in the $\delta$; the basal patch on each elytron triangularly extending backwards and sometimes coalescent with the subapical one along the middle of the disc. There is no tendency in these examples to approach $E$. martini or its var. natalensis, Pic.

\section{Ebceus alboguttatus, sp. n.}

․ Moderately elongate, robust, rather convex, widened posteriorly, shining, clothed with fine scattered pubescence intermixed with long, semierect, black, bristly hairs ; rufotestaceous, the outer joints of the antennæ more or less infuscate, the head (a posteriorly-biangulate flavous space in front excepted), scutellum, and metasternum black; the lateral and basal margins of the prothorax and the elytra (the reddish apex excepted) white or yellowish-white, each elytron with a very large triangular, apically-produced basal patch (reaching the suture) and a broad, angulate, subapical fascia, these markings narrowly coalescent down the middle of the disc, black; the wings fusco-variegate; the head and prothorax almost smooth, the elytra closely, finely (at the base more strongly) punctured. Head narrower than the prothorax ; antennæ short, not very slender, subserrate. Prothorax transverse, rounded at the sides. Elytra moderately long. Legs rather stout.

万. Antenuæ longer; anterior tarsal joint 2 rather stout, long, nigro-pectinate along the entire outer edge; elytra less dilated posteriorly, each deeply excavate before the tip, the apical margin obliquely thickened, produced, bidentate, the suture bearing a stout blackish spiniform process within the cavity.

Length $3 \frac{4}{5}-4 \mathrm{~mm}$. (o $q$.)

Hab. S. Africa (Mus. Cape Town); Namwala [iii. 1913] and Namwazi [vi. 1914], N.W. Rhodesia (H. C. Dollman).

Thirteen specimens, including four males. Near E.(Mixis) rufithorax, Pic, the black elytral markings narrowly coalescent down the middle of the disc (leaving sharply-defined whitish patches), the antennæ shorter ; the elytral apices of the $\delta$ obliquely polished, bidentate, deeply excavate, nigrospinose within. 


\section{Ebceus ornatipennis.}

Attalus (?) ornatipennis, Gorh. Ann. \& Mag. Nat. Hist. (7) v. p. 77 $\left(\right.$ o $q$ ) $(1900)^{1}$.

๙. Anterior tarsal joint 1 very short, 2 elongate, prolonged over 3 above, nigro-pectinate along the entire outer edge and tip ; intermediate tibiæ simple; elytra transversely excavate at the apex, the suture of each elytron bearing before the tip a long, erect, compressed, apically-ciliate appendage, which is armed with a triangular tooth at the middle behind, the sutural angles slightly produced, upturned, and dentiform.

Hab. Rhodesia, Salisbury ${ }^{1}$ (Mus. Brit., Mus. Durban: ठํ ), Mwengwa (H. C.Dollman: 13. xii. 1913, 1.v. 1914: q).

Thirteen specimens seen, all $q q$ but two. The elytral appendages of the $\delta$ were not described by Gorham, though very similar to those of his E. (Attalus) ridens. The anterior tarsi in the same sex are formed as in the similarly-coloured, much larger E. (Mixis) simoni, Ab. The black subapical annulus is complete in the $q$, and open posteriorly or horseshoe-shaped in the $\delta$. The black basal portion of the head is triangularly produced in front on each side between the eyes.

\section{Ebøus crassicauda, sp. n.}

๙. Moderately elongate, widened behind, shining, sparsely clothed with fine pubescence intermixed with longer bristly hairs; testaceous, the basal half of the head, the scutellum, and metasternum black; the lateral and basal margins of the prothorax and the elytra yellowish-white, each elytron with a large, triangular, backwardly-produced basal patch and an outwardly-extended triangular patch beyond the middle (the latter not reaching the suture), these markings coalescent down the middle of the disc, and a small triangular sutural spot before the tip, black; the head and prothorax almost smooth, the elytra finely punctulate. Head nearly as wide as the prothorax; antemnæ rather slender, serrate. Prothorax transverse. Elytra somewhat produced at the apex, transversely excavate before the tip, the suture of each bearing a long, stout, compressed, hooked appendage immediately behind the subapical spot, the sutural angle sharply produced. Anterior tarsal joint 2 nigro-pectinate along the outer edge. 
Length $3 \frac{1}{3} \mathrm{~mm}$.

Hab. S. Africa, Leslies, near Umtali, Manica (Dr. Marshall : 25. x. 1897).

One male. Of the same general coloration as E. (Malachius) consobrinus, Boh., the head more broadly testaceous in front; the elytra with a small additional spot before the tip, and the large patch preceding it subtriangular and not extending so far backward, the puncturing more distinct; the $\delta$-appendages stout, and abruptly hooked or angulate as seen in profile.

\section{Ebceus bicaudatus.}

Urodactylus bicaudatus, J. Thoms. Archives Ent. ii. p. 80, t. 1. tigs. 5, $5 a\left(0^{*}\right)^{1}$ (1858).

Attalus (Mixis) bizonatus, Ab. de Perrin, Rev. d'Ent. xix. p. 177 (1900) $\left(0^{*}\right)^{2}$.

๙ . Anterior tarsal joint 2 extending over 3 above, nigropectinate at the tip ; intermediate tibiæ simple; posterior tibiæ sinuate, slightly infuscate in the middle, and nigromaculate at the tip; elytra with the subapical nigroviolaceous fascia extending for some distance down the suture, the apices transversely excavate and each with a long, compressed, concave appendage arising from near the suture, the appendages abruptly constricted beyond the middle, and with the apical portion curved downwards, hook-like, and pointed at the tip.

․ Autennæ shorter, feebly serrate; elytral fasciæ transverse.

Hab. W. Africa, Gaboon ${ }^{1}$ (type of Thomson), Sierra Leone (Mus. Brit.: of $q$ ), Dakar, Senegal ${ }^{2}$ (type of Abeille de Perrin, ô).

The British Museum possesses a pair of this species, acquired in 1858. Thomson's enlarged figure of the elytral appendages is misleading (they are not 3 -segmented as shown by him), and he does not mention or show the sinuate, nigro-maculate posterior tibiæ of the male, a character noted by Abeille de Perrin. The antennæ are testaceous and sharply serrate. The base of the head is black. E. (Urodactylus) uncipennis, Pic (1903), from San Thomé, is an allied insect with differently-marked elytra.

\section{Ebceus maculipes, sp. $\mathrm{n}$.}

․ Elongate, widened posteriorly, shining, clothed with scattered pallid pubescence intermixed with long, erect, 
black, bristly hairs ; testaceous, the margins of the prothorax and the elytra whitish, the latter with a basal and subapical fascia nigro-violaceous; the head and prothorax almost smooth, the elytra finely punctured and sometimes (in immature specimens) with two raised lines on the disc. Head narrower than the prothorax; antennæ short, rather slender, feebly serrate. Prothorax broad, transverse, rounded at the sides, the margins dilated posteriorly. Elytra a little wider than the prothorax. Posterior tibiæ feebly curved.

๙̃. Antennæ longer and more strongly serrate; anterior tarsal joint 2 projecting over the base of 3, nigro-pectinate along the apical margin; posterior tibiæ curved, arcuately dilated at the base within, and nigro-maculate at the apex ; elytra subparallel, the apices excavate and strongly angulatoappendiculate, as in the same sex of E. bicaudatus.

Var. 1. Narrower, the basal half of the head, the front of the prothorax (owing to the covered base of the head showing through the transparent chitin), and two coalescent triangular spots on the disc at the base, black; the other characters $(\delta q)$ as in the type. [Rhodesia.]

Var. 2. The base of the head to a variable extent black, the metallic basal fascia of the elytra hollowed behind, the subapical one somewhat curved, narrow or incomplete; the other characters $(\delta q)$ as in the type. [Rhodesia and Masai Reserve.]

Length 3-4 $\mathrm{mm}$.

Hab. S. Africa, Kashitu, north of Broken Hill (H. C. Dollnan: xii. 1914, i. 1915: o $q$ ), and Salisbury, Rhodesia (Dr. Marshall: ix. $1900 ;$ đo), Port Natal (ex coll. Fry: ơ, type), Frere (Mus. Cape Town: o ); E. Africa, Masai Reserve (Capt. Luckman: 4. iii. 1914: q).

Three $\delta \delta$, four $q q$, the pair from Natal, which are similarly coloured, being taken as the types, the three males agreeing in structure. E. maculipes is the eastern representative of E. bicaudatus, Thoms. (= bizonatus, Ab.), differing from it in the shape of the posterior tibiæ of the $\delta$; the elytral appendages are similarly shaped in the two species.

\section{Ebceus ridens.}

Attalus ridens, Gorh. Ann. \& Mag. Nat. Hist. (7) vii. p. 356 (ठ) $(1901)^{\perp}$.

๙ิ. Anterior tarsal joint 2 prolonged over 3, nigropectinate at the tip; intermediate tibiæ simple; elytra 
transversely excavate and plicate at the tip, the apices subangularly produced, the suture of each elytron bearing a long, compressed appendage which is furnished with a downwardly-curved, hook-like pencil of hairs at the apex, and also with a small angular prominence before the angle.

Hab. Rhodesia, Old Umtali in Mashonaland ${ }^{1}$ (Dr. Marshall).

There are two $\delta \delta$ and one $q$ of this species in the British Museum. It may be known from E. (Mixis) rufithorax, Pic, and other very similarly coloured insects by the red head and under surface, and the elongate appendages of the elytra, these being nearly as long as in the same sex of E. bicaudatus, Thoms. The subapical black patch is broad, transverse, and subcrescentiform. Gorham compares his insect with Philhedonus (Anthocomus) felix, which has simple 4 -jointed anterior tarsi in $\delta$.

\section{Ebceus exquisitus.}

Attalus (Mixis) exquisitus, Ab. de Perrin, Rev. d'Ent. xix. pp. 164, $176(1900)\left(\sigma^{7}+\right)^{1}$.

๙. Antennæ short, subserrate; anterior tarsal joint 2 extending over 3 above, nigro-pectinate at tip; elytra deeply excavate at the apex, the excavation preceded by the flattened, apically-constricted, pointed, porrect appendage arising from the suture of each elytron, the sutural angle somewhat pointed as seen from above, raised and subfoliaceous as seen in profile.

$H a b$. S. Africa, Hebron, near Kimberley ${ }^{1}$ (types of Abeille de Perrin), Salisbury, Bulawayo, and Umfuli River (Dr. Marshall), Caia, Zambesi (H. Swale), Mwengwa and Namwala, Rhodesia, Livingstone, Zambesi (H. C. Dollman).

The long series of this species before me includes several males. A rufo-testaceous insect; the elytra subopaque, with a small triangular spot on each side of the scutellum, and a common, irregular, $\mathbf{X}$ - or $\mathbf{H}$-shaped mark extending across the disc to near the outer margin, black, the apex and a humeral patch red, and the rest of the surface (like the basal margin of the prothorax) whitish. The $\delta$ type has been lent me by Dr. Péringuey.

E. (Mixis) michaelseni, Pic (1914), from Omaruru, S.W. Africa, is an allied form.

\section{Ebæus sudanicus, sp. n.}

․ Elongate, widened posteriorly, shining, sparsely 
clothed with short bristly hairs; testaceous, the prothorax rufescent, whitish along the basal margin, the elytra with three large whitish patches-one common, elongate, lanciform, extending down the anterior half of the suture, and one, somewhat rounded, on the disc of each elytron beyond the middle-the two post-median spots enclosed by a pyriform nigro-fuscous annulus which extends inward to the suture and narrowly and obliquely forward to the base in one specimen, the scutellum, metasternum, and abdomen slightly infuscate; the head and prothorax almost smooth, the elytra closely, very finely punctured. Head a little narrower than the prothorax, the latter strongly transverse ; antennæ subserrate, rather short; elytra moderately long.

Length $2 \frac{1}{4} \mathrm{~mm}$.

Hab. Sudan, Wad Medani (H. H. King: 31. iii. 1920). Two females, found "on cotton." Smaller than the S. African E. exquisitus, Ab., amœnulus, Boh., etc., the elytra each with a large, pyriform, blackish, post-median annulus, which is continued obliquely forward to the base in one specimen, so as to partly or entirely enclose three large whitish patches.

\section{Ebaus confluens, sp. n.}

q. Elongate, rather narrow, widened posteriorly, shining, the elytra in great part opaque, clothed with fine pubescence intermixed with long, erect, blackish hairs ; the head, the four or five outer joints of the antennæ, a median vitta on the prothorax (sometimes reduced to a spot at the apex), the scutellum, and metasternum black, the rest of the prothorax rufescent, with the lateral and basal margins yellowish-white, the antennal joints $1-6$, the abdomen, and the legs wholly or in part (the intermediate and posterior femora, and sometimes the tibiæ also, often in part black or infuscate), testaceous; the elytra with a common oblong or oval spot on the suture below the hase, an oblong space on each side of it externally and a subapical patch running forward along the suture, whitish or flavous, the rest of their surface (a reddish space at the tip excepted) black; the head and prothorax almost smooth, the elytra closely, finely punctulate. Head narrower than the prothorax ; antennæ rather short, moderately serrate. Prothorax broader than long, obliquely narrowed posteriorly. Elytra moderately long.

ऽ. Antennæ much longer, more sharply serrate ; anterior tarsal joint 2 produced over 3 , nigro-pectinate at tip ; elytra 
less widened posteriorly, transversely excavate and obliquely, bilamellately produced at the tip, the lower lamella forming a hook-like upward dilatation of the sutural angle.

Var.? havilandi, n.-Antennal joint 1 infuscate above; prothorax with a broad anteriorly-dilated black median vitta; elytra opaque, black, with four sharply-defined white spotstwo on the suture and one on each lateral margin. ( $q$.)

Length $2 \frac{1}{2}-3 \mathrm{~mm}$. ( $\delta$ q .)

Hab. N.W. Rhodesia, Kashitu, N. of Broken Hill [vi., vii. 1915], Mwengwa [vii., viii. 1913, v. 1914] (H. C. Dollman: type) ; Natal, Estcourt (Haviland, in Mus. Cape Town: o , var.).

Two $\delta \delta^{\pi}$, five $q$ o , three with complete vitta on the prothorax and the legs (the anterior pair excepted) partly black. The Natal form is perhaps specifically distinct. Smaller, narrower, and less robust than E. alboguttatus, the apices of the elytra differently shaped in $\delta$; the appendages, too, are short, compared with those of E. consobrinus, Boh.

\section{Ebaus consubrinus.}

‥ Malachius consobrinus, Boh. Ins. Caffr. i. 2, p. 464 (1851) ${ }^{1}$.

๙ . Smaller, narrower, and less robust than E. alboguttatus, the general coloration similar, except that the antennæ are testaceous, the tips of the posterior tibiæ are sometimes infuscate, and the subapical black fascia of the elytra is not emarginate on the middle of the disc behind; elytra closely, minutely punctate, transversely excavate at the tip, the suture of each of them bearing a very long, narrow, pointed, downwardly-curved appendage towards the apex and a slender dentiform process above the apical angle; legs slender; anterior tarsal joint 2 nigro-pectinate at the tip.

․ Antennæ shorter.

Var. Head with the base only black; the elytra with the elongate basal portion of the black mesially-constricted dorsal stripe narrower, leaving a rufo-testaceous humeral patch, the former sometimes completely separated from the subapical fascia.

Length $2 \frac{3}{4}-3 \mathrm{~mm}$.

Hab. S. Africa, Chirinda, Mashonaland (Dr. Marshall: xi. 1901 : đo), Malvern, Natal (Mus. Durban : o $q$ ), Mfongosi, Zululand (Mus. Cape Town: ₹), Gariep River ${ }^{\text {. }}$

Various specimens from the above-quoted localities seem to be referable to $E$. consobrinus, Boh., the type ( $q$ ) of which, captured in the Gariep River district, has a rufo-testaceous 
head. The form with a reddish humeral patch and the head black at the base approaches $E$. (Mixis) exquisitus, Ab., amcenulus, Boh., and transvaalensis, Pic (1911); it was found at Malvern and in Zululand. The much smaller size, the very fine elytral puncturing, and the long apical appendages in $\sigma^{\pi}$ distinguish $E$. consobrinus from $E$. alboguttatus, the last-mentioned character and the testaceous antennæ separating it from E. confluens.

\section{Ebaus argus.}

o. Attalus (Mixis) argus, Ab. de Perrin, Rev. d'Ent. ix. p. 51 (1890) $)^{4}$.

ơ. "Elytra ... ad apicem laciniata et plicata, ubi plicatura duobus angulis instructa, toto apice flavo." [Ab. de Perrin. $]$

ๆ. Elongate-subtriangular, shining, clothed with sparse pubescence intermixed with long erect hairs; testaceous, the head (a subtriangular patch in front excepted), elytra (except a common oblong-oval patch ou the suture below the base, an elongate mark at the sides in line with it, but extending forward to beneath the humeri, a large subtriangular spot on the disc near the apex, and a triangular patch at the apex itself, which are flavous or testaceous), metasternum, and abdomen in part, black; the head and prothorax very sparsely, minutely, the elytra somewhat closely and strongly, punctate. Head small, bi-impressed in front; antennæ rather short, serrate. Prothorax transverse, rounded at the sides, the margins explanate and obliquely convergent posteriorly. Elytra elongate, broader at the base than the prothorax, rapidly widening to near the apex, the latter rounded.

Length $4 \frac{1}{2} \mathrm{~mm}$.

Hab. Abyssinia ${ }^{1}$ (Raffray, ex coll. Sharp).

There is a $q$ of this species in the British Museum. The elytral markings resemble those of Hedybius formosus, Reiche, except that there is an additional flavous subapical spot on the disc of each elytron.

\section{Ebaus albopartitus, sp. n.}

$\delta$. Elongate, rather broad, slightly widened posteriorly, the elytra opaque, the rest of the surface shining, clothed with fine pubescence intermixed with long, blackish, bristly hairs; head black, pale yellow in front, the black basal portion triangularly extending forward on each side anteriorly; the prothorax rufescent, the expanded lateral and basal margins 
flavescent; the scutellum and two very large subquadrate patches on each elytron (the basal one longer than broad, the other shorter, neither of them reaching the suture or outer margin) black, the rest of the elytra, the rufo-testaceous apex excepted, white; the antennæ, legs, and under surface (the black lateral portions of the meso- and metasternum excepted) testaceous ; the head and prothorax almost smooth, the elytra densely punctulate. Head a little narrower than the prothorax, transversely grooved between the eyes; antennæ serrate, rather stout. Prothorax transverse, obliquely narrowed posteriorly. Elytra flattened on the disc, transversely excavate, plicate, and explanate at the apex, the sutural angle obtusely foveate within. Anterior tarsal joint 2 rather long, produced over 3 above, nigropectinate along the entire outer edge. Ventral segment 6 cleft down the middle.

Length $4 \mathrm{~mm}$.

$H a b$. E. Africa, W. shore of Lake Nyasa, between Domira Bay and Kotakota (Dr. Neave: x. 1910).

One male. A remarkably distinct form with two large, subquadrate, black patches on each elytron, the rest of their surface (the tip excepted) white.

\section{Ebaus simoni.}

Attalus (Mixis) simoni, Ab. de Perrin, Rev. d'Ent. xix. pp. 164, 176 (1900) (o 우 $)^{1}$.

․ Elongate, robust, rather broad, widened posteriorly, shining, clothed with fine pubescence intermixed with long, erect, blackish setæ; rufo-testaceous or testaceous, the basal half of the head, the scutellum, and under surface (the abdomen excepted) black, the anterior portion of the head, the basal and lateral margins of the prothorax, and the elytra whitish, the elytra each with a large subquadrate spot or patch at the base (not reaching the suture or outer margin), and a horseshoe-shaped mark towards the apex, black; the elytra densely, rather strongly, the head and prothorax sparsely, extremely minutely punctate. Head narrower than the prothorax, feebly bi-impressed between the eyes; antennæ moderately long, rather slender, joints $4-10$ obconic. Prothorax broader than long, rounded and explanate at the sides, and also explanate at the base. Elytra wider than the prothorax, conjointly rounded at the apex. Legs stout.

$\delta$. Antennæ a little longer, joints 5-11 infuscate at the tip in one specimen ; anterior tarsal joint 1 short, 2 elon- 
gate, extending over 3 above, and with a conspicuous black comb extending along the entire outer edge and tip ; intermediate tibiæ twisted, arcuately dilated and closely ciliate near the base within ; elytra subparallel, the apices triangularly produced, excavate, the suture of each elytron bearing a short, compressed, sub-bidentate, ciliate appendage before the rather acute angle.

Length $4-4 \frac{1}{2} \mathrm{~mm}$. ( $\delta$ \% .)

Hab. S. Africa, Hebron, near Kimberley ${ }^{1}$ (types of Abeille de Perrin) ; Lichtenburg, Transvaal (Dr. Brauns); Salisbury and Bulawayo (Dr. Marshall), and Namwala, Rhodesia (H. C. Dollman).

Redescribed from seven specimens, including four $\delta \hat{\delta}$, captured at various dates between November and March. The type has been lent me by Dr. Péringuey. Larger and more elongate than E. rufithorax, var. rhodesianus, Pic, and very similarly coloured, except that the subapical black patch is horseshoe-shaped as in E. ornatipennis, Gorh., ס ; the $\delta$ with twisted, basally dilated, intermediate tibiæ, and the apices of the elytra appendiculate and triangularly produced.

\section{Ebæus inermipennis.}

? Attalus (Mixis) inermipennis, Pic, Mélanges exot.-entom. xxv. p. 3 ( o ) $(1917)^{1}$.

Extremely like E. simoni, Ab., the head broadly testaceous or whitish in front in both sexes; the black basal patch on the elytra oblong, concave within, reaching the scutellum in front, the subapical patch arcuate.

๙ . Anterior tarsal joint 2 elongate, produced over 3 above, with a black comb extending along the entire outer edge; intermediate tibiæ simple ; elytra very deeply, transversely grooved at the apex, the apices themselves broadly subtruncate, tumid, and somewhat explanate, the groove bordered in front near the suture by a short transverse plica.

Length $4-4 \frac{1}{2} \mathrm{~mm}$. ( $\delta$ \& .)

Hab. S. Africa, Port Natal ${ }^{1}$ (type of Pic), Headlands, Mashonaland (Dr. Marshall: xi. 1897).

A pair from Mashonaland seem to be referable to this species. E. (Mixis) inermipennis, in Pic's "description abrégée," is compared with E. ridens, Gorh., and the elytral apices of the $\delta$ are said to be "tumefactis, non spinosis." 


\section{Ebrus sinuatipes, sp. n.}

Elongate, rather broad, widened posteriorly, shining, the elytra subopaque, sparsely, finely pubescent with scattered, erect, black, bristly hairs intermixed; rufo-testaceous, the head (the anterior margin excepted) and metasternum black, the margins of the prothorax whitish, the elytra flavous, each with two large black patches-the basal one transversely subquadrate, the subapical one broad, arcuate, neither reaching the suture, but both extending to the outer margin; the head and prothorax sparsely, minutely, the elytra densely, finely punctate. Head, antennæ, prothorax, etc., as in E. simoni, Ab.

o. Anterior tarsal joint 2 extending over 3 above, nigropectinate at tip ; intermediate tibiæ sinuate within, arcuately dilated near the base; elytra each with a tumid, oblique, sinuate, concave area at the apex, the swollen portion preceded by a short transverse groove extending across the suture, the apices narrowly truncate.

Length $3 \frac{1}{2}-3 \frac{3}{4} \mathrm{~mm}$. (o 우.)

Hab. S. Africa, Melsetter, Mashonaland [type], and Upper Tongaat, Barwon, Natal (Dr. Marshall: x., xii. 1901).

One pair. Very like E. ridens, Gorh., and E. inermipennis, Pic; the elytral apices of the $\delta$ are tumid and without appendages as in the latter, and the intermediate tibiæ in the same sex are sinuate within, but less strongly so than in E. simoni, Ab.

\section{Ebceus rufithorax.}

Attalus (Mixis) rufithorax, Pic, L'Echange, xx. p. 33 (o 9 ) (1904) ${ }^{1}$.

$\delta$. Head black (as in $q$ ); antennæ moderately long, feebly serrate; anterior tarsal joint 2 extended over 3 above, nigro-pectinate at tip; intermediate tibiæ simple; elytra truncate and transversely excavate at the apex, the depression limited exteriorly by a stout conical tubercle.

Var.? Head broadly testaceous in front ( $q$ ).

Attalus (Mixis) rufithorax, var. rhodesiana, Pic, op. cit. xxiii. p. 131 ( ㅇ) $(1907)^{2}$.

Hab. S. Africa, Dunbrody ${ }^{1}$ (Mus. Cape Town, Mus. Brit.), George, Cape Colony (Dr. Brauns: 우), Bedford, Cape Colony, and Malvern, Natal (Mus. Durban), Mwengwa, Rhodesia $^{2}$ (H. C. Dollman: 15.iv. 1914: var., ㅇ ).

Four $\delta$ o from Dunbrody are before me, as well as others Ann. \& Mag. N. Hist. Ser, 9. Vol. ix. 
of the same sex from Bedford and Malvern; two $q q$ from Rhodesia are doubtless referable to the variety named by Pic. This insect has the general coloration of $E$. ridens, Gorh., except that the head is partly or wholly black; the basal black patch on each elytron is large and reaches the suture, and the subapical one arcuate, showing a tendency to form an incomplete annulus in one of the two females from George.

\section{Ebcus ephippiatus, sp. n.}

q. Elongate, widened posteriorly, the elytra opaque, the rest of the surface shining, finely pubescent, with longer semierect hairs intermixed ; black, the antennal joints 1-6, prothorax (a transverse dark space in front and the whitish lateral margins excepted), tarsi, and tibiæ (the posterior pair at the apex only), and the anterior and intermediate femora in part, testaceous; the elytra each with a complete, oblique, suturally-widened, ante-median fascia, and a common oval spot before the apex (the latter connected with a testaceous spot at the sutural angle),whitish; the head and prothorax almost smooth, the elytra alutaceous and excessively minutely punctate. Head bi-impressed in front; antennæ short, slender, subserrate. Prothorax transverse, small, convex, rounded at the sides, much narrowed behind, the lateral margins explanate posteriorly. Ely tra rather long, becoming convex towards the apex. Legs slender; posterior tibiæ curved.

Length $2 \frac{2}{3} \mathrm{~mm}$.

Hab. S. Africa, Duubrody (Mus. Cape Town).

One $q$, captured in December 1912 on Mimosa. A sharply maculate form with the elytra marked very much as in the Natal insect named by Pic E. (Anthonomus) martini, the latter having an opaque, broader, and more narrowly margined prothorax. The variable $E$. dunbrodensis (ante No.5), specimens of which are before me, is also somewhat similar. Till the $\delta$ is found, E. ephippiatus cannot be located with certainty.

\section{Ebaus bonnefoii.}

? Attalus (Mixis) bonnefoï, Pic, Mélang'es exot.-entom. xxv.p. 3 (q) (1917).

Hab. S. Africa, Transvaal (type of Pic), Sterkfontein (H. P. Thomasset, in Mus. Brit.: \&), Howick, Natal (J. Cregoe, in Mus. Durban: ?). 
Four females before me seem to belong here. They have the black patches on the elytra larger-the anterior one subtriangular and nearly reaching the suture, and the curved subapical one angulate in front and extending downward exteriorly behind. E. bonnefoii is probably a variety of $\boldsymbol{E}$. inermipennis, the head being black at the base in both insects; but till the $\delta$ is found they are best treated as distinct.

\section{Ebcus quadrisignatus, sp. n.}

․ Moderately elongate, widened posteriorly, shining, clothed with fine pubescence intermixed with long, erect hairs; testaceous or rufo-testaceous, the lateral and basal margins of the prothorax and the elytra pale yellowish or whitish, the basal half of the head, the scutellum, two large patches on each elytron-one basal, triangular (extending inwards to the suture), the other oblique, subangulate anteriorly, on the disc towards the apex (reaching the outer margin, but not the suture)-and the metasternum black; the head and prothorax almost smooth, the elytra closely, very finely punctured. Head much narrower than the elytra; antennæ short, serrate. Prothorax broad, strongly transverse. Elytra moderately long, at the base not wider than the prothorax.

Length $2 \frac{4}{5}-3 \mathrm{~mm}$.

Hab. Rhodesia, Old Umtali, Mashonaland (Dr. Marshall: x., xi. 1897).

Three $q q$. Smaller than $E$. rufithorax, Pic, the elytra more shining, the black subapical patch oblique, not emarginate behind, the anterior one triangular, the head testaceous in front.

\section{Ebœus quadrinotatus, sp. n.}

+ . Larger and more robust than E. quadrisignatus ; the head black to the anterior margin, transversely depressed or excavate in the middle between the eyes; the prothorax a little less transverse, obliquely narrowed posteriorly; the elytra each with two very large nigro-violaceous spots-one basal, transverse, rounded or subangulate behind, the other on the disc towards the apex larger, rounded, extending outwards to the lateral margin ; the metasternum black; the intermixed erect hairs on the upper surface long, blackish.

Length $3 \frac{3}{4}-4 \mathrm{~mm}$.

Hab. S. Africa, Malvern, Natal [type] (Dr. Marshall: 
ii. 1896, vii. 1903); Mpanzi Mioti (Mus.Durban); Seymour, Cape Colony (Mus. Cape Town).

Five females, precisely similar, and best treated as specifically distinct from $E$. quadrisignatus, in the absence of males of either of them. E. (Attulus) transvaalensis, Pic (1911), type also $q$, not identified amongst the material before me, is said to have the subapical black mark in the form of a sinuate fascia, and it must therefore be different from $E$. quadrinotatus.

\section{Ebaus zonarius, sp. n.}

q. Elongate, rather broad, shining, thickly clothed with very long, erect, black bristly hairs intermixed with fine pubescence; testaceous, the basal half of the head, the metasternum, scutellum, and two very large patches on each elytron-one triangular (reaching the suture), the other in the form of a very broad, anteriorly-rounded, subapical fascia (not quite reaching the suture or outer margin)black, the rest of the elytra yellowish-white; the head and prothorax faintly punctulate, the elytra densely, very finely punctured. Head narrower than the prothorax; antennæ rather slender, moderately long, subserrate. Prothorax broader than long, obliquely narrowed posteriorly, the lateral and basal margins rather broadly explanate and reflexed. Elytra widened posteriorly.

Length $3 \frac{1}{2} \mathrm{~mm}$.

Hab. Abyssinia (Raffray, ex coll. Sharp).

One female. This species is coloured like the Nyasa $E$. albopartitus, except that the large black basal patch on the elytra is triangular and extended inwards to the suture, and the subapical one is less elongate. The elytra, too, are more shining and the antennæ not so stout. E. zonarius cannot be identified with any of the allied Abyssinian forms described by Abeille de Perrin in 1890, four of these having nigro-trimaculate elytra.

\section{Ebaus nyasanus, sp. n.}

९. Elongate, slightly widened behind, shining, sparsely clothed with fine pubescence intermixed with longer bristly hairs; testaceous, the head to the anterior margin (the labrum pale flavous), scutellum, and metasternum black; the lateral and basal margins of the prothorax and six spots or patches on the elytra-one, common, elongate-oval, extending down the suture below the base, one on each side in 
a line with it (running forwards along the outer margin), one, rounded, on the disc of each towards the apex, and a common transverse apical patch-yellowish-white or flavous, the rest of the elytral surface brownish-black; the head and prothorax almost smooth, the elytra densely, finely punctate. Head nearly as wide as the prothorax; antennæ rather short, serrate. Prothorax broader than long, obliquely narrowed posteriorly. Elytra moderately long.

Length $3-3 \frac{1}{2} \mathrm{~mm}$.

Hab. E. Africa, Nyasa (Mus. Brit.).

Two specimens. Differs from the allied southern and Rhodesian forms with longitudinally-confluent black markings in having a rather large, rounded, additional whitish subapical spot on each elytron. The elytra themselves are doubtless excavate and appendiculate in $\delta$.

\section{Ebœus amœnulus.}

․ Malarhius amœenulus, Boh. Ins. Caffraria, i. 2, p. 463 (1851).

Hab. S. Africa, Natal.

A co-type of this insect, communicated by Dr. Sjöstedt, agrees with $E$. (Mixis) exquisitus, Ab., in having a red head; but it has the elytral markings more like those of $E$. crassicauda and E. consobrinus, the black mesially-constricted dorsal stripe extending forward to the base (leaving the humeri testaceous) and inward to the suture beyond the middle.

\section{Ebøus tetrazona, sp. n.}

q. Rather broad, widened posteriorly, moderately elongate, the elytra opaque, the rest of the surface shining, finely pubescent, with longer, semierect, black, bristly hairs intermixed ; rufo-testaceous, the antennal joints 5-11, palpi, base of head broadly, scutellum, two large transverse patches on each elytron (one basal, the other subapical, not reaching the suture or outer margin), posterior tibiæ, tarsi in part, metasternum, and abdomen in great part, black; the head and prothorax almost smooth, the elytra closely, finely, rugulosely punctate. Head much narrower than the prothorax; antennæ short, sharply serrate from joint 5 onward. Prothorax convex, transverse, obliquely narrowed posteriorly. Elytra moderately long, with a smoother, somewhat convex area at the apex. Legs rather stout.

Var. + . Smaller and less robust; the head at the base, 
and the outer joints of the antennæ, very slightly infuscate; the legs testaceous, the intermediate femora at the base, and the posterior femora with the basal half or more, black; legs more slender.

Length 3-4 mm.

Hab. Rhodesia, Salisbury (Mus. Cape Town : 23. ix. 1915; Dr. Marshall: x. 1900 ; var.).

Four $q q$, the two larger ones selected as the types. Not unlike E. (Attalus) ridens, Gorh. The elytra less shining and with the black subapical patch transverse, instead of arcuate. E. nigrofemoratus, the of which has pectinate antennæ, is also somewhat similarly marked, except that it has the post-median spot large and rounded. In the Durban Museum there is a small $q$, taken at Upper Tongaat in 1901, with the head, antennæ, and legs black, and the subapical mark very large and rounded, that may belong to the same species.

\section{Ebreus cavicauda, sp. n.}

§. Moderately elongate, rather broad, the elytra opaque, the rest of the surface shining, very finely pubescent with longer semierect hairs intermixed; the eyes, base of the head, scutellum, metasternum, and abdomen in great part, black, the antennæ, the rest of the head, prothorax, and legs wholly testaceous, the elytra olive-green, with the excavated apices black; the head and prothorax almost smooth, the elytra alutaceous and extremely minutely punctate. Head rather broad, flattened in front; antennæ long, strongly dentate from joint 4 onward. Prothorax transverse, explanate and strongly rounded at the sides, much narrowed posteriorly, at the middle distinctly wider than the base of the elytra. Elytra moderately long, parallel at the base and somewhat arcuately widened posteriorly, the apices rather broadly produced, deeply, transversely excavate, separately rounded at the tip, the eavity smooth and shining within. Anterior tarsal joint 2 rather long, extending over 3 above, nigro-pectinate along the oblique apical margin; posterior tibiæ strongly bisinuate.

Length $3 \mathrm{~mm}$.

Hab. S. Africa, Grahamstown (O'Neil, in Mus. Cape Town).

One male. Separable from E. conigerus, $\delta$ (ante No. 1), by the olive-green opaque elytra, the longer, dentate, testaceous antennæ, the relatively broader, explanate prothorax, 
the black scutellum, the non-dentate, excavate, produced apices of the elytra, and the bisinuate posterior tibiæ.

\section{Ebcus ramicornis.}

o. Anthocomus ramicornis, Boh. Ins. Caffr. i. 2, p. 469 (1851) ${ }^{1}$ ?

‥ Attalus africanus, Pic, L'Echange, xx. p. 26 (1904) ${ }^{2}$ ?

o. Ebceomorphus ramicornis, Pic, l.c. p. $28^{3}$.

o. Ebcomorphus natalensis, Pic, Bull. Soc. Ent. Fr. 1917, p. $235^{4}$.

ऽ. Antennæ long, flabellate; elytra with the apex rufotestaceous, excavate, and bilamellate ; anterior tarsal joint 2 nigro-pectinate at the tip.

ๆ. Antennæ shorter, serrate; elytra wholly metallic.

Length $2 \frac{1}{2} \mathrm{~mm}$. ( $\delta$ \% $\%$ )

Hab. Natal ${ }^{1-4}$, Malvern, E. London (Mus. Durban, Mus. Cape Town: of o), Zululand (ex coll. Fry: $q$ ).

Specimens of the two sexes of this insect have been sent me by Dr. Péringuey and Mr. C. Barker. Boheman's type $(\delta)$ is described as having black elytra, with the apex rufotestaceous, that of Pic $(\delta)$ being metallic, except at the tip, the diagnoses agreeing in other respects. The black patch on the disc of the prothorax varies in development, and in the $q$ it is sometimes reduced to a large spot in front. The numerous $\delta$ examples before me agree with Pic's description of that sex; the $q$ might easily be mistaken for an Attalus.

\section{Ebaus dichrous, sp. n.}

q. Rather short, broad, much widened posteriorly, shining, finely sericeo-pubescent; head (the eyes excepted), the antennal joints $1-5$ in part (1 nigro-lineate above, and 6-11 more or less infuscate), prothorax, and legs (the slightly infuscate tarsi excepted) testaceous, the elytra cyaneous, the scutellum, metasternum, and abdomen piceous or black; the head and prothorax almost smooth, the elytra very finely, rather closely punctate. Head broad; antennæ long, serrate from joint 5 onward. Prothorax strongly transverse, much wider than the head, rounded at the sides, the margins somewhat expanded. Elytra subarcuately dilated from a little below the base, depressed along the suture anteriorly.

Length $3 \mathrm{~mm}$.

Hab. Natal, Malvern (Mus. Durban).

Two of $q$, labelled as having been captured on July 25th, 1901. Larger and broader than E. ramicornis ( $q$ ), the head, prothorax, and legs testaceous. Till the $\delta$ is found, $E$. dichrous can be placed near that species. E. conigerus is a 
more robust insect, and is somewhat similarly coloured. A co-type of $\boldsymbol{E}$. dichrous has been placed in the British Museum.

\section{Ebaus apricus.}

‥ Anthocomus apricus, Gorh. Ann. \& Mag. Nat. Hist. (7) v. p. 78 (1900) $)^{1}$.

․ Attalus sublimbatus, Pic, L'Echange, xxiii. p. 131 (1907) 2.

Var. o. Ebceomorphus transvaalensis, Pic, Bull. Soc. Ent. Fr. 1917, p. $2355^{3}$.

Var. ․ Ebceomorphus transvaalensis, var. rufo-apicalis, Pic, Mélanges exot.-entom. xxv. p. 3 (1917) ${ }^{4}$.

ô. Antennæ long, pectinate; elytra slightly produced at the tip, depressed and transversely grooved before the apex, the apical portion tumid; anterior tarsal joint 2 elongated, reaching the apex of 3 above, and nigro-pectinate along the outer edge and at the tip; terminal dorsal segment of abdomen rather long, narrow, sulcate, testaceous.

q. Antennæ shorter, serrate; terminal dorsal segment of abdomen shorter and broader, black.

Hab. S. Africa, Estcourt ${ }^{1}$ and Frere, Natal, Salisbury, Bulawayo $^{2}$ (Mus. Brit.; Mus. Cape Town), Reenen (Mus. Durban), Transvaal ${ }^{3}{ }^{4}$.

Numerous males and females seen, including a specimen ( $q$ ) of the var. rufo-apicalis, Pic. The of E. apricus has the testaceous apical marking of the elytra extending further forward along the suture and rather broadly connected externally with the lateral patch. The elytra are wholly black in the $\delta$ named by Pic; the apex only is rufo-testaceous in his E. rufo-apicalis. The upper surface of the body is sparsely clothed with long hairs intermixed with the shorter decumbent pubescence. The Natal specimens ( $\delta q)$ in the Cape Town Museum are labelled Anthocomus ramicornis, Boh., which has the prothorax red, with a black patch on the disc.

\section{Ebcus pectinimanus, sp. n.}

q. Moderately elongate, rather broad, shining, the elytra subopaque, finely pubescent, without longer hairs intermixed; black, the elytra with a common oval space below the base, extending down the suture to the large triangular apical patch, and a triangular space at the sides below the humeri, testaceous, the antennæ in great part and legs (the posterior femora, and the others at the base, excepted) also 
testaceous ; the head and prothorax very sparsely, the elytra densely, extremely minutely punctate. Head narrower than the prothorax, bi-impressed in front; antennæ short, serrate. Prothorax large, convex, transverse, rounded at the sides, narrowly margined. Elytra at the base about as wide as the prothorax, moderately long, subparallel.

б. Antennæ, legs, and the two terminal abdominal segments, testaceous, the testaceous markings on the elytra more extended, the sutural and lateral patches broadly connected with the pallid apical space ; head a little broader, the eyes more prominent; antennæ much longer, strongly pectinate; elytra each with an arcuate excavation towards the apex, the apical portion somewhat narrowly produced, raised and strongly tumid along the suture; anterior tarsal joint 1 short, 2 elongate, reaching the apex of 3 aboye, and with a black comb extending along the outer edge; pygidium rather long and narrow, sulcate at tip.

Length $3 \mathrm{~mm}$. ( $\quad$ o $q$.)

Hab. S. Africa, Bulawayo (Dr. Marshall: $\delta$ ㅇ ), Lonely, Rhodesia (H. Swale: $q$ ).

One $\delta$, seven $q$ 우. Very near E. (Anthocomus) apricus, Gorh., the elytra with a common oval testaceous space before the middle, connected along the suture with the apical patch; the $\delta$ with shorter, pectinate antennæ, the elytral apices more swollen beyond the subapical sulcus and narrowly produced, and the last two abdominal segments testaceous. E. apricus was also found at Bulawayo.

\section{Ebcus nigrofemoratus, sp. n.}

$q$. Moderately elongate, widened posteriorly, finely pubescent, without long hairs intermixed, the elytra opaque, the rest of the surface shining; black, the three basal joints of the antennæ beneath, prothorax, elytra, tibiæ, and bases of the tarsi testaceous or rufo-testaceous; the elytra with a common transverse patch at the base, extending narrowly outwards to the humeri, and a large rounded spot on the disc of each towards the apex, black; the head and prothorax very sparsely, minutely, the elytra closely, very finely, punctate. Head small, much narrower than the prothorax; antennæ serrate, rather slender, short. Prothorax transverse, convex, obliquely narrowed posteriorly. Elytra much broader than the prothorax, comparatively short.

$\delta$. Antennæ long, pectinate; anterior tarsal joint 2 elongated, reaching the apex of 3 above, nigro-pectinate along 
the outer edge; pygidium sharply sulcate; elytra obliquely truncate and hollowed towards the sutural angle, the apices a little smoother.

Length $3-3 \frac{1}{5} \mathrm{~mm}$. (ơ $q$.)

Hab. Natal, Frere and Estcourt (Dr. Marshall: x. 1892, ix. 1896, i. 1897).

Three $\delta^{\pi} \delta$, three $q q$. Not unlike E. apricus, Gorh., but very differently coloured, the head smaller; the elytra without apical excavation in $\delta$, the pygidium broad, black, and sulcate in the same sex.

Alphabetical numbered list of species of Ebrus enumerated in this paper; those marked with an asterisk are treated as new.

*alboguttatus, 7 .

*albopartitus, 18.

amonulus, 29.

apricus, 34 .

argus, 17.

bicaudatus, 10 .

bonnefoii, 24 .

*cavicauda, 31 .

* confluens, 15.

* conigerus, 1 .

consobrinus, 16 .

*crassicauda, 9 .

*dichrous, 33 .

dunbrodensis, 5 .

*ephippiatus, 23.

exquisitus, 13.

inermipennis, 20.

*maculipes, 11.

martini, 4.

*nairobianus, 2.

*nigrofemoratus, 36 .

*nyasanus, 28.

ornatipennis, 8 . *pectinimanus, 3 5.

*quadrinotatus, 26.

*quadrisignatus, 25.

ramicornis, 32 .

ridens, 12.

*rubricatus, 3.

rufithorax, 22 .

*sericatus, 6 .

simoni, 19.

*sinuatipes, 21 .

*sudanicus, 14.

*tetrazona, 30 .

*zonarius, 27.

Synonyms, Varieties, etc. africanus, 32.

bizonatus, 10.

*havilandi, 15 .

natalensis, 4, 32 .

rhodesiana, 22.

rufo-apicalis, 34 .

sublimbatus, 34 .

transvaalensis, 34 .

\section{XXVI.-Descriptions and Reeords of Bees.-XCII.} By T. D. A. Cockerell, University of Colorado.

$$
\text { Andrena prococella, Cockerell, } 1917 .
$$

Col. C. G. Nurse took this species in abundance at Quetta, March 1903. The female is new, and is so unlike the male that it requires a separate description.

q.-Length about $11 \mathrm{~mm}$.

Black, with the second and third abdominal segments, and broad apex of first, bright ferruginous; the second segment 


\section{$2 \mathrm{BHL}$ Biodiversity Heritage Library}

Champion, G. C. 1922. "XXV.-The African species of Ebæus, Er., with an account of their accessory ${ }^{x}$-characters [Coleoptera]." The Annals and magazine of natural history; zoology, botany, and geology 9, 217-242. https://doi.org/10.1080/00222932208632665.

View This Item Online: $\underline{\text { https://www.biodiversitylibrary.org/item/53480 }}$

DOI: https://doi.org/10.1080/00222932208632665

Permalink: https://www.biodiversitylibrary.org/partpdf/52317

\section{Holding Institution}

Smithsonian Libraries

\section{Sponsored by}

Smithsonian

\section{Copyright \& Reuse}

Copyright Status: Public domain. The BHL considers that this work is no longer under copyright protection.

This document was created from content at the Biodiversity Heritage Library, the world's largest open access digital library for biodiversity literature and archives. Visit BHL at https://www.biodiversitylibrary.org. 